\title{
СТРАТЕГІЯ РОЗВИТКУ ПАЛІАТИВНОЇ ДОПОМОГИ В УКРАЇНІ НА ПЕРІОД ДО 2027 РОКУ
}

\author{
Г. М. Курницька \\ Міжнародний благодійний фонд «Карітас», м. Львів
}

\begin{abstract}
У статті розглянуто та висвітлено Стратегію розвитку паліативної допомоги в Україні на період до 2027 p. і план заходів щодо ії реалізації. На сьогодні в Україні створено 2 центри, 7 хоспісів та понад 60 самостійних відділень паліативної допомоги, що забезпечує доступ до 1500 стаціонарних паліативних ліжок, при рекомендованій Всесвітньою організацією охорони здоров’я потребі у 3500 ліжок. Крім того, в Україні функціонує лише 7 виїзних служб надання паліативної допомоги вдома для дорослих та дітей. За оцінками експертів, потреба у паліативній допомозі в Україні задоволена лише на $15 \%$.

Стратегія пропонує системно врегулювати організаційні основи надання паліативної допомоги, зокрема розробити правові та організаційні механізми, що стимулюють ефективну діяльність в сфері охорони здоров’я і забезпечують розвиток мережі паліативних установ охорони здоров’я.
\end{abstract}

\section{STRATEGY FOR THE DEVELOPMENT OF PALLIATIVE CARE IN UKRAINE UP TO 2027}

\section{H. M. Kurnytska}

\section{International Charitable Foundation «Caritas», Lviv}

\begin{abstract}
In the article the Strategy of development of palliative care in Ukraine for the period till 2027 and the plan of measures for its realization are considered and covered. To date, 2 centers, 7 hospices and more than 60 independent palliative care units have been established in Ukraine, providing access to 1500 permanent palliative beds, with 3500 beds recommended by the World Health Organization. In addition, there are only 7 outbound palliative care services for adults and children at home. According to expert estimates, the need for palliative care in Ukraine is satisfied by only $15 \%$.

The strategy proposes to systematically regulate the organizational basis for the provision of palliative care, in particular, develop legal and organizational mechanisms that stimulate effective health care activities and ensure the development of a network of palliative care institutions.
\end{abstract}

Вступ. Забезпечення реалізації прав і свобод людини і громадянина, визначених Конституцією України, а також виконання Стратегії сталого розвитку «Україна - 2020» щодо впровадження в Україні європейських стандартів життя, Стратегії державної політики щодо наркотиків на період до 2020 р., вимагає визнати права тяжкохворих пацієнтів та створити умови для досягнення максимальної якості життя для паліативних пацієнтів усіх вікових категорій [2].

у 2014 р. Всесвітня організація охорони здоров'я визначила, що паліативна допомога - це підхід, що дозволяє поліпшити якість життя пацієнтів (дітей і дорослих) та їхніх сімей, які стикнулися з проблемами, пов'язаними із захворюванням, що загрожують

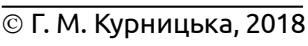

життю, шляхом запобігання та полегшення страждань за рахунок раннього виявлення, ретельної оцінки та лікування болю та інших фізичних симптомів, а також надання психосоціальної та духовної підтримки. Надання паліативної допомоги основане на принципі поваги до людської гідності та спрямоване на надання практичної підтримки родинам паліативних пацієнтів.

Обов'язок держави забезпечити доступ до паліативної допомоги всім пацієнтам, незалежно від віку, нозологічної категорії захворювання, соціального статусу, національності, релігійних та політичних переконань, місця перебування тощо. 3 огляду на постаріння населення та високі демографічні показники смертності, адже щорічно в Україні помирає близько 700 тис. населення, в тому числі понад 100 тис. від онкологічних хвороб [11], зростає потреба в орга- 
нізації та наданні якісної паліативної допомоги. Кількість населення, що потребує паліативної допомоги складає понад 600 тис. пацієнтів щорічно [10], плюс члени їхніх родин потребують супроводу та підтримки. Тобто щорічно понад 1,5 млн населення потребують паліативної допомоги.

Протягом останніх років досягнуто певного прогресу в сфері надання паліативної допомоги, зокрема прийнято Закон України «Про внесення змін до Основ законодавства України про охорону здоров'я щодо удосконалення надання медичної допомоги» участині визначення паліативної допомоги як виду медичної допомоги та організаційних засад їі надання, закони України «Про затвердження Загальнодержавної програми боротьби з онкологічними захворюваннями на період до 2016 року» [4], «Про затвердження Загальнодержавної цільової соціальної програми протидії захворюванню на туберкульоз на 2012-2016 роки» [5] «Про затвердження Загальнодержавної цільової соціальної програми протидії ВІЛ-інфекції/ СНІДу на 2014-2018 роки» [6], які містять питання розвитку паліативного догляду.

Основна частина. МОЗ розробило проект Стратегії розвитку паліативної допомоги в Україні на період до 2027 р. і план заходів щодо їі реалізації [1].

Передбачено створення соціально-медичних центрів, які надаватимуть комплекс послуг паліативним пацієнтам та членам їхніх сімей.

Відзначають, що в Україні зростає потреба в наданні якісної паліативної допомоги - понад 600 тис. пацієнтів потребують паліативної допомоги щорічно. Також вимагають супроводу і підтримки члени їхніх сімей. За підрахунками авторів Стратегії щорічно, більше 1,5 млн людей потребують паліативної допомоги.

На сьогодні в Україні створено 2 центри, 7 хоспісів та понад 60 самостійних відділень паліативної допомоги, що забезпечує доступ до 1500 стаціонарних паліативних ліжок, при рекомендованій Всесвітньою організацією охорони здоров'я потребі у 3500 ліжок. Крім того, в Україні функціонує лише 7 виїзних служб надання паліативної допомоги вдома для дорослих та дітей. За оцінками експертів, потреба у паліативній допомозі в Україні задоволена лише на 15 \% [10].

Водночас відзначається низький рівень поінформованості різних верств населення, органів державної влади та місцевого самоврядування щодо паліативної допомоги, недостатнє нормативно-правове регулювання у сфері надання паліативної допомоги, відсутність системного підходу до організації її надання, міжвідомчої співпраці та інтегрованого підходу в цій сфері з урахуванням пацієнторієнтованого підходу.

Ця Стратегія визначає мету, завдання, першочергові пріоритети та індикатори становлення та розвитку паліативної допомоги в Україні та відповідає гарантіям держави, взятим відповідно до Конвенції про захист прав людини і основоположних свобод [8], Конвенції про права дитини, та напрямам розвитку, визначеним у Резолюції Шістдесят сьомої сесії Всесвітньої Асамблеї Здоров'я (2014) [9] «Зміцнення системи надання паліативної допомоги як компонента комплексного лікування в системі догляду за хворими» [7].

Стратегія пропонує системно врегулювати організаційні основи надання паліативної допомоги, зокрема розробити правові та організаційні механізми, що стимулюють ефективну діяльність в сфері охорони здоров'я і забезпечують розвиток мережі паліативних установ охорони здоров'я.

Також передбачено:

- розвиток кадрових ресурсів для роботи стаціонарних і виїзних служб паліативної допомоги;

- створення системи мотивації та заохочення для залучення кадрів, які надають паліативну допомогу;

- створення нової спеціальності молодшого медичного працівника - «доглядальниця»;

- проведення наукових досліджень нозологічних, соціальних, психологічних та інших особливостей паліативного стану дітей та внесення відповідних змін до чинних медичних стандартів і клінічних протоколів, розробка нових медичних стандартів і клінічних протоколів [3].

Стратегія ґрунтується на таких принципах, як:

- пацієнторієнтований підхід;

- законність, дотримання прав людини, гуманність та повага до людської гідності;

- відкритість, чесність і координованість системи паліативної допомоги;

- посилення підтримуючих систем охорони здоров'я, соціальної політики та інших;

• постійні наукові та операційні дослідження;

- доступність лікарських засобів для забезпечення високої якості життя паліативних пацієнтів;

- участь громадськості у створенні та функціонуванні системи паліативної допомоги;

- виконання взятих міжнародних зобов'язань [2].

Метою Стратегії $\epsilon$ створення системи паліативної допомоги та забезпечення гарантованого доступу до неї пацієнтів всіх вікових категорій, незалежно від місця перебування [2]. 
У формуванні заходів та реалізації Стратегії в межах своїх повноважень беруть участь МО3, Мінсоцполітики, Міносвіти, МВС, Держлікслужба, місцеві державні адміністрації та органи місцевого самоврядування (за згодою), заклади охорони здоров'я, громадські, професійні, релігійні об'єднання, наукові установи, благодійні фонди тощо.

\section{Моніторинг та оцінка}

Напрями, за якими оцінюють результати реалізації Стратегії:

- оцінювання кожні три роки потреб у паліативній допомозі для визначення досягнутого рівня задоволення потреб та необхідного перегляду заходів для якісного функціонування системи паліативної допомоги;

- нормативно-правове врегулювання сфери надання паліативної допомоги та доступу до знеболювання для пацієнтів різних вікових категорій незалежно від місця їх перебування;

- здійснення фінансування паліативної допомоги з різних джерел фінансування;

- відповідність існуючих сервісів (стаціонарних та мобільних) для різних вікових категорій визначеним національним потребам із урахуванням регіональної специфіки;

- впровадження навчальних програм до- та післядипломної освіти для медичних та соціальних, педагогічних працівників, психологів, волонтерів, духівників;

- забезпеченість сервісів (стаціонарних та мобільних) достатньою кількістю медичного персоналу 3 відповідним розрахунком навантаження, а також соціальними працівниками, педагогами, психологами, духівниками [2].

\section{За кількісними показниками:}

- кількість затверджених відповідних нормативноправових актів, що регулюють сферу паліативної допомоги та відповідають стандартам Всесвітньої організації охорони здоров'я, інших міжнародних організацій;

- кількість стаціонарних ліжок паліативної допомоги для дорослих та дітей відповідно до визначених потреб;

- кількість мобільних сервісів паліативної допомоги для дорослих та дітей відповідно до визначених потреб;

- кількість денних центрів для дорослого та дитячого населення відповідно до визначених потреб;

- підвищення доступності до паліативної допомоги облік різниці між попитом та фактично наданими послугами паліативної допомоги;
- кількість відпущених опіоїдів за госпітальним та аптечним відпуском, з них пільгових;

- кількість отриманих опіоїдів на території адміністративної одиниці (область, місто, район);

- кількість аптек в областіммісті, що мають ліцензію на провадження діяльності, пов'язаної з обігом наркотичних, психотропних речовин та прекурсорів;

- визначений обсяг квот, у динаміці, по Україні відповідно до наданих даних міжнародним комітетом із контролю за наркотиками [2].

\section{За якісними показниками:}

- проведення моніторингу та оцінки якості надання паліативної допомоги серед пацієнтів та членів їхніх родин за допомогою стандартизованого дослідження;

- летальність на лікарняному ліжку;

- дослідження відповідності призначень щодо лікування болю затвердженим клінічним протоколам за участю незалежних експертів;

- наявність/укомплектованість у центрах (відділеннях) посад психологів, соціальних працівників. Залучення священнослужителів [2].

Висновки. Етапи реалізації Стратегії визначаються планом заходів із їі реалізації, що затверджується Кабінетом Міністрів України.

Реалізація Стратегії сприятиме впровадженню єдиної державної політики з розвитку паліативної допомоги, що забезпечить:

- створення доступної та ефективної системи надання паліативної допомоги на основі застосування кращих світових практик, міжнародних стандартів та підходів, наукових розробок вітчизняних та зарубіжних фахівців, з метою забезпечення відповідної якості життя паліативних пацієнтів та членів їхніх родин;

- створення оптимальної мережі установ та сервісів, що надають паліативну допомогу, різної форми власності й підпорядкування та організаційних форм;

- допомогу та підтримку сім'ям, які опинилися у складних життєвих обставинах;

- координацію надання паліативної допомоги закладами та установами охорони здоров'я, соціального захисту різного рівня та різних відомств, а також недержавної форми власності;

- створення системи взаємодії установ та закладів охорони здоров'я та соціального захисту населення;

- створення комплексної системи до- та післядипломної підготовки фахівців, які залучені до надання паліативної допомоги;

- створення системи мотивації і заохочення для залучення кадрів, які надають паліативну допомогу; 
- забезпечення широкої участі благодійних, громадських, релігійних та інших неурядових організацій та об'єднань громадян у питаннях забезпечення та розвитку паліативної допомоги;

- створення цільових фінансових програм на різних рівнях фінансування паліативної допомоги та підвищення ефективності, раціонального та цільового використання бюджетних коштів;

- створення механізмів залучення позабюджетних коштів до системи паліативної допомоги.

\section{СПИСОК ЛІТЕРАТУРИ}

1. Юрліга [Електронний ресурс]. - Режим доступу : http://jurliga.ligazakon.ua/

2. Ліга паліативної допомоги [Електронний ресурс]. Режим доступу : http://ligalife.com.ua/4932/

3. Режим доступу : http://ckp.in.ua/news/11358

4. Режим доступу: https://docs.dtkt.ua/ua/doc/1146.430.0

5. Режим доступу : http://www.document.ua/prozatverdzhennja-zagalnoderzhavnoyi-cilovoyi-socialnoyi-prdoc120652.html

6. Режим доступу : https://www.apteka.ua/article/226613

7. World Health Organization. (2016). Planning and implementing palliative care services: a guide for programme managers. World Health Organization. [Electronic source]. Mode access : http://www.who.int/iris/handle/10665/250584
У результаті реалізації Стратегії будуть створені оптимальні умови для правового, економічного та організаційного забезпечення надання паліативної допомоги, що сприятиме доступності паліативних пацієнтів та членів їхніх родин до якісної паліативної допомоги.

Реалізація Стратегії здійснюється за рахунок коштів державного та місцевих бюджетів, інших джерел.

8. Конвенціяпрозахист правлюдинита основоположних свобод [Електронний ресурс]. - Режим доступу : http:// search.ligazakon.ua/I_doc2.nsf/link1/MU50K02U.html

9. Резолюції Шістдесят сьомої сесії Всесвітньої Асамблеї Здоров'я (2014 рік) [Електронний ресурс]. - Режим доступу : http://pandia.ru/text/80/097/14695.php

10. Комітет з питань охорони здоров'я провів засідання «круглого столу» на тему: «Сучасний стан надання паліативної допомоги дорослому населенню, міжнародний досвід та перспективи розвитку в Україні» [Електронний ресурс]. - Режим доступу : http:// narodnarada.info/news/komitet-pitan-ohoroni-zdorovyaproviv-news-24856.html

11. Статистика випадків онкологічних захворювань [Електронний ресурс]. - Режим доступу : http://studcon. org/statystyka-vypadkiv-onkologichnyh-zahvoryuvan

Отримано 05.04.18 